\title{
Identifying clinically relevant drug resistance genes in drug-induced resistant cancer cell lines and post-chemotherapy tissues
}

\author{
Mengsha Tong ${ }^{1}$, Weicheng Zheng ${ }^{1}$, Xingrong Lu ${ }^{2}$, Lu Ao ${ }^{1}$, Xiangyu Li $^{1}$, Qingzhou \\ Guan ${ }^{1}$, Hao Cai ${ }^{1}$, Mengyao Li ${ }^{1}$, Haidan Yan ${ }^{1}$, You Guo ${ }^{1}$, Pan Chi ${ }^{2}$, Zheng Guo ${ }^{1}$ \\ ${ }^{1}$ Department of Bioinformatics, Key Laboratory of Ministry of Education for Gastrointestinal Cancer, Fujian Medical University, \\ Fuzhou, China \\ ${ }^{2}$ Department of Colorectal \& Anal Surgery, Affiliated Union Hospital of Fujian Medical University, Fuzhou, China \\ Correspondence to: \\ Zheng Guo, e-mail: guoz@ems.hrbmu.edu.cn \\ Pan Chi, e-mail: chipan@yeah.net \\ Keywords: drug-induced resistant cancer cell lines, drug treatment response, colorectal cancer, 5-fluorouracil, oxaliplatin \\ Received: June 30, $2015 \quad$ Accepted: September 12, $2015 \quad$ Published: October 15, 2015
}

\section{ABSTRACT}

Until recently, few molecular signatures of drug resistance identified in druginduced resistant cancer cell models can be translated into clinical practice. Here, we defined differentially expressed genes (DEGs) between pre-chemotherapy colorectal cancer (CRC) tissue samples of non-responders and responders for 5 -fluorouracil and oxaliplatin-based therapy as clinically relevant drug resistance genes ( CRG $\left._{5-\mathrm{Fu} / \mathrm{L}-\mathrm{OHP}}\right)$. Taking CRG $_{5-\mathrm{Fu} / \mathrm{L}-\mathrm{OHP}}$ as reference, we evaluated the clinical relevance of several types of genes derived from HCT116 CRC cells with resistance to 5-fluorouracil and oxaliplatin, respectively. The results revealed that DEGs between parental and resistant cells, when both were treated with the corresponding drug for a certain time, were significantly consistent with the $\mathrm{CRG}_{5-\mathrm{FU} / \mathrm{L}-\mathrm{OHP}}$ as well as the DEGs between the postchemotherapy CRC specimens of responders and non-responders. This study suggests a novel strategy to extract clinically relevant drug resistance genes from both druginduced resistant cell models and post-chemotherapy cancer tissue specimens.

\section{INTRODUCTION}

Differentially expressed genes (DEGs) between parental and drug-induced resistant cells are frequently regarded as drug resistance genes [1-6] and used to identify predictive markers of therapeutic benefit [7-9]. However, findings of such studies can be hardly translated into clinical practice [10-14]. It has been recognized that genes identified from drug-induced resistant cell models may simply represent drug-induced transcriptional changes that may be irrelevant to resistance mechanisms [15]. Therefore, alternative experimental approaches have been proposed.

Stevenson et al. introduced three in vitro gene lists [9]: (i) DEGs between parental and resistant cells [termed basally deregulated (BD) genes]; (ii) DEGs between parental and drug-treated parental cells [inducible in the parental cells (IP) genes], and (iii) DEGs between resistant and drug-treated resistant cells [inducible in the resistant cells (IR) genes]. They considered the pathways significantly enriched with any of the three types of genes as drug resistance pathways. Apparently, both IP and IR genes may mainly represent drug-induced changes, and their relevance to drug resistance is unclear. Allen et al. proposed that the overlap between BD genes and IP genes might represent drug resistance genes [16, 17]. However, because $\mathrm{BD}$ and IP genes represent sustained and transient drug-induced changes, respectively, their overlaps may still be irrelevant to drug resistance. Munkácsy et al. proposed that IP genes should be excluded from BD genes [18]. However, some IP genes could be drug resistance genes, and it is difficult to determine which IP genes should be excluded. In contrast to the aforementioned studies, Li et al. proposed that DEGs between a drug-induced resistant cell and its parental cell, both of which have undergone drug treatment for a defined time, might represent targets for 
therapies aimed at reversing drug resistance [19]. Here, we define this type of DEG as inducible difference (ID) genes, which represent the difference between two cell types in response to drug treatment. Given this diversity of definition for candidate drug resistance genes, it is necessary to evaluate the clinical relevance of various genes identified in cell models.

Another problem is that, in microarray or RNAsequencing experiments that compare two types of cell lines, usually only two or three technical replicates are generated. Because commonly used statistical methods, such as Significance Analysis of Microarrays (SAM) [20] and variation analysis [21], often have insufficient statistical power when the sample sizes are small [22-24], the FC method is frequently applied to select DEGs in such small-scale cell line experiments [25-27]. However, genes that are highly expressed in both cells can hardly reach large FCs. Moreover, genes with low expression levels in both cell types may reach large FCs owing simply to measurement variations, resulting in false positives [28]. In contrast, the average difference (AD) method can identify genes that are highly expressed in both cells and show large absolute differences, even if the FCs in their expression levels are small [23, 29]. Notably, genes with high expression levels are likely to participate in some biologically conserved pathways, such as metabolism and membrane trafficking $[29,30]$ Hence, it is necessary to leverage its value in detecting drug resistance genes in small-scale cell line experiments.

In this study, we defined DEGs between prechemotherapy clinical tissue samples of responders and non-responders for 5-fluorouracil and oxaliplatin-based therapy as clinically relevant drug resistance genes $\left(\mathrm{CRG}_{5 \text {-FU/L-OHP }}\right)$. By analyzing the transcriptional profiles of drug-induced resistant cell models, we showed that $\mathrm{BD}$ genes mainly reflected drug treatment response and were inconsistent with $\mathrm{CRG}_{5-\mathrm{FU} / \mathrm{L}-\mathrm{OHP}}$. In contrast, ID genes, especially when selected according to the AD ranking method, were significantly consistent with $\mathrm{CRG}_{5-\mathrm{FU} / \mathrm{L}-\mathrm{OHP}}$ We also found that ID genes were significantly consistent with DEGs between the post-chemotherapy CRC specimens of responders and non-responders, which provided compelling evidence for the use of postchemotherapy CRC specimens for identifying genes relevant to drug resistance.

\section{RESULTS}

\section{BD genes are significantly consistent with IP genes}

The IP genes were denoted as $\mathrm{IP}_{6}, \mathrm{IP}_{12}$ and $\mathrm{IP}_{24}$ for the conditions in which the parental cells underwent drug treatment for 6, 12 and 24 hours, respectively. In the E-MEXP-390 dataset (Table 1), we selected the top-ranked $3000 \mathrm{BD}$ genes and the IP genes for 5-FU with the largest
FC values. The consistency scores (the percentage of genes that had the same deregulation directions, see Methods) of $\mathrm{BD}$ genes with $\mathrm{IP}_{6}, \mathrm{IP}_{12}$ and $\mathrm{IP}_{24}$ were $97.16 \%, 98.42 \%$ and $98.13 \%$, respectively (binomial test, all $P$-values $<1.11 \mathrm{E}-16$, Table 2). When ranking genes by $\mathrm{AD}$, the corresponding consistency scores were $90.92 \%, 90.96 \%$ and $86.85 \%$ (binomial test, all $P$-values $<1.11 \mathrm{E}-16$, Table 1). Similarly, significant consistency between BD genes and $\mathrm{IP}_{6}, \mathrm{IP}_{12}$ and $\mathrm{IP}_{24}$ genes of L-OHP was observed (binomial test, all $P$-values $<1.11 \mathrm{E}-16$, Table 1 ). When comparing the top-ranked $1500 \mathrm{BD}$ genes and IP genes, the same results were observed (Supplementary Table 1).

Subsequent analysis of HCT116 SN-38-resistant cells and doxorubicin-resistant cells from four cancer types (gastric, pancreatic, colon and breast) in the GSE3926 dataset revealed similar results (Supplementary Table 2).

\section{Clinically relevant drug resistance genes}

We defined DEGs between pre-chemotherapy tissue samples of non-responders and responders of CRC patients treated with 5-FU and L-OHP-based therapy as clinically relevant drug resistance genes, denoted as $\mathrm{CRG}_{5-\mathrm{FU} / \mathrm{L}-\mathrm{OHP}}$. The GSE19860 and GSE28702 datasets (Table 1), which were both generated by the Affymetrix microarray GPL570 platform, included samples for a total of 25 nonresponders and 19 responders of metastatic CRC patients treated with mFOLFOX6 chemotherapy, respectively. We combined the two datasets together to detect 2033 DEGs(FDR < 0.2) using the RankProduct method which is resistant to experimental batch effects [31]. Then, we detected 179 DEGs (FDR < 0.2) between the 4 nonresponders and 4 responders of metastatic CRC patients treated with 5-FU and L-OHP in the E-MEXP-3368 dataset. As the mFOLFOX6 regimen also included 5-FU and L-OHP, the overlapped genes of the two lists of DEGs should be $\mathrm{CRG}_{5 \text {-FU/L-OHP }}$ and consistent in deregulation directions under the assumption that the drugs used together in each of the chemotherapy regimens have no or limited antagonistic effects against with each other (Supplementary Methods). In fact, the two lists of DEGs had 82 overlapped genes and the consistency score was $79.27 \%$ (binomial test, $P$-value $<5.15 \mathrm{E}-07$ ). This result suggested that $\mathrm{CRG}_{5 \text {-Fu/L-OHP }}$ could be detected robustly in the independent datasets. It also provided evidence for the assumption that the drugs used in combination had no or limited antagonistic effects against with each other. Finally, the 315 DEGs detected with FDR $<0.2$ in a dataset and with $P$-value $<0.05$ in another dataset were treated as the final $\mathrm{CRG}_{5 \text {-FU/L-oHP }}$ (Supplementary Table3).

We additionally analyzed the GSE52735 dataset which included samples for 14 non-responders and 23 responders of metastatic CRC patients treated with a combination chemotherapy including fluoropyrimidine (5-FU and capecitabine, an oral prodrug of 5-FU). 
Table 1: Datasets analyzed in this study

\begin{tabular}{|c|c|c|c|c|c|}
\hline Cell line & Dataset & Platform & Drug & Sensitive & Resistant \\
\hline HCT116(colon) & E-MEXP-390 & GPL570 & $5-\mathrm{FU}$ & 3 & 3 \\
\hline HCT116(colon) & E-MEXP-390 & GPL570 & L-OHP & 3 & 3 \\
\hline HCT116(colon) & E-MEXP-1691 & A-AFFY-101 & $5-\mathrm{FU}$ & 3 & 3 \\
\hline HCT116(colon) & E-MEXP-1691 & A-AFFY-101 & SN38 & 3 & 3 \\
\hline HCT116(colon) & E-MEXP-1171 & GPL570 & SN38 & 3 & 3 \\
\hline \multicolumn{6}{|l|}{$\begin{array}{l}\text { EPP85- } \\
\text { 181P(pancreatic) }\end{array}$} \\
\hline EPG85-257P(gastric) & GSE3926 & GPL96 & Doxo & 1 & 1 \\
\hline \multicolumn{6}{|l|}{ HT29(colon) } \\
\hline \multicolumn{6}{|l|}{ MCF-7(breast) } \\
\hline $\begin{array}{l}\text { DLD1;HT29; } \\
\text { LS513;Lovo;(colon) }\end{array}$ & GSE10405 & GPL2006 & SN38 & 1 & 1 \\
\hline \multicolumn{6}{|c|}{ The CRC tissue data used for identifying CRGs } \\
\hline Stage & Dataset & Platform & Therapeutic regimen & $\mathbf{R}$ & NR \\
\hline IV & GSE19860 & GPL570 & mFOLFOX6 & 3 & 14 \\
\hline IV & GSE28702 & GPL570 & mFOLFOX6 & 16 & 11 \\
\hline IV & E-MEXP-3368 & A-AFFY-101 & 5-FU and L-OHP & 4 & 4 \\
\hline IV & GSE52735 & GPL570 & 5-FU-based & 23 & 14 \\
\hline IV & GSE69657 & GPL570 & FOLFOX6 & 13 & 17 \\
\hline
\end{tabular}

Abbreviations: 5-FU: 5-fluorouracil; L-OHP:Oxaliplatin;SN38: an active metabolite of irinotecan; Doxo: Doxorubicin; R:Responder;NR:Non-responder;

Table 2: The consistency scores of the top-ranked $3000 \mathrm{BD}$ and $\mathrm{IP}_{6}, \mathrm{IP}_{12}, \mathrm{IP}_{24}$ genes detected from HCT1116 cell line

\begin{tabular}{|c|c|c|c|c|c|c|c|}
\hline Dataset & Cell line & Drug & Method & IP & $\begin{array}{c}\text { Overlapped } \\
\text { DEG }^{\mathrm{a}}\end{array}$ & $\begin{array}{l}\text { Consistent } \\
\operatorname{DEG}^{\mathrm{b}}(\%)\end{array}$ & Binominal $P$-value \\
\hline \multirow{6}{*}{ E-MEXP-390 } & \multirow{6}{*}{ HCT116 } & \multirow{6}{*}{ 5-FU } & FC & \multirow{2}{*}{$\mathrm{IP}_{6}$} & 1198 & 97.16 & $<1.11 \mathrm{E}-16$ \\
\hline & & & $A D$ & & 2026 & 90.92 & $<1.11 \mathrm{E}-16$ \\
\hline & & & $\mathrm{FC}$ & \multirow{2}{*}{$\mathrm{IP}_{12}$} & 1457 & 98.42 & $<1.11 \mathrm{E}-16$ \\
\hline & & & $\mathrm{AD}$ & & 2091 & 90.96 & $<1.11 \mathrm{E}-16$ \\
\hline & & & FC & \multirow{2}{*}{$\mathrm{IP}_{24}$} & 1229 & 98.13 & $<1.11 \mathrm{E}-16$ \\
\hline & & & $\mathrm{AD}$ & & 2045 & 86.85 & $<1.11 \mathrm{E}-16$ \\
\hline \multirow{6}{*}{ E-MEXP-390 } & \multirow{6}{*}{ HCT116 } & \multirow{6}{*}{ L-OHP } & FC & \multirow{2}{*}{$\mathrm{IP}_{6}$} & 1898 & 98.84 & $<1.11 \mathrm{E}-16$ \\
\hline & & & $\mathrm{AD}$ & & 2409 & 98.22 & $<1.11 \mathrm{E}-16$ \\
\hline & & & FC & \multirow{2}{*}{$\mathrm{IP}_{12}$} & 1833 & 99.95 & $<1.11 \mathrm{E}-16$ \\
\hline & & & $\mathrm{AD}$ & & 2298 & 96.52 & $<1.11 \mathrm{E}-16$ \\
\hline & & & $\mathrm{FC}$ & \multirow{2}{*}{$\mathrm{IP}_{24}$} & 1402 & 99.29 & $<1.11 \mathrm{E}-16$ \\
\hline & & & $\mathrm{AD}$ & & 2214 & 91.64 & $<1.11 \mathrm{E}-16$ \\
\hline
\end{tabular}

(Continued) 


\begin{tabular}{|c|c|c|c|c|c|c|c|}
\hline Dataset & Cell line & Drug & Method & IP & $\begin{array}{c}\text { Overlapped } \\
\text { DEG }^{\mathrm{a}}\end{array}$ & $\begin{array}{l}\text { Consistent } \\
\text { DEG }^{\text {( }} \% \text { (\%) }\end{array}$ & Binominal $P$-value \\
\hline \multirow{2}{*}{ E-MEXP-1691 } & \multirow{2}{*}{ HCT116 } & \multirow{2}{*}{$5-\mathrm{FU}$} & $\mathrm{FC}$ & \multirow{2}{*}{$\mathrm{IP}_{24}$} & 1838 & 98.80 & $<1.11 \mathrm{E}-16$ \\
\hline & & & $\mathrm{AD}$ & & 2409 & 94.69 & $<1.11 \mathrm{E}-16$ \\
\hline \multirow{2}{*}{ E-MEXP-1691 } & \multirow{2}{*}{ HCT116 } & \multirow{2}{*}{ SN38 } & $\mathrm{FC}$ & \multirow{2}{*}{$\mathrm{IP}_{24}$} & 1934 & 98.29 & $<1.11 \mathrm{E}-16$ \\
\hline & & & $\mathrm{AD}$ & & 2423 & 95.00 & $<1.11 \mathrm{E}-16$ \\
\hline \multirow{6}{*}{ E-MEXP-1171 } & \multirow{6}{*}{ НCT116 } & \multirow{6}{*}{ SN38 } & $\mathrm{FC}$ & \multirow{2}{*}{$\mathrm{IP}_{6}$} & 1341 & 96.20 & $<1.11 \mathrm{E}-16$ \\
\hline & & & $\mathrm{AD}$ & & 1974 & 81.26 & $<1.11 \mathrm{E}-16$ \\
\hline & & & FC & \multirow{2}{*}{$\mathrm{IP}_{12}$} & 1059 & 88.48 & $<1.11 \mathrm{E}-16$ \\
\hline & & & $\mathrm{AD}$ & & 1987 & 82.94 & $<1.11 \mathrm{E}-16$ \\
\hline & & & $\mathrm{FC}$ & \multirow{2}{*}{$\mathrm{IP}_{24}$} & 1079 & 86.75 & $<1.11 \mathrm{E}-16$ \\
\hline & & & $\mathrm{AD}$ & & 2033 & 86.77 & $<1.11 \mathrm{E}-16$ \\
\hline
\end{tabular}

Abbreviations: DEG: differentially expressed genes; BD: basally deregulated genes; IP: inducible parental genes; 5-FU: 5-fluorouracil; L-OHP: oxaliplatin; SN38: an active metabolite of irinotecan;

${ }^{a}$ The number of $\mathrm{BD}$ genes overlapped with IP genes;

${ }^{b}$ The consistency score of BD genes and IP genes;

${ }^{c}$ The binominal distribution $P$-value.

Using the RankProduct method, we detected 1805 DEGs (FDR $<0.2)$ between the non-responders and responders and they overlapped with 167 of the $315 \mathrm{CRG}_{5 \text {-FU/L-OHP }}$ As the three combination chemotherapy regimens shared 5-FU only, the overlapped DEGs should represent $\mathrm{CRG}_{5-\mathrm{FU}}$ and consistent in deregulation directions in the three gene lists (Supplementary Methods). In fact, the consistency score for the 167 overlapped genes was $78.44 \%$ (binomial test, $P$-value $=7.39 \mathrm{E}-11$ ). This result suggested that CRGs for 5-FU could be detected robustly in independent datasets. The 131 DEGs consistently detected in the three datasets were defined as the final $\mathrm{CRG}_{5-\mathrm{FU}}$ (Supplementary Table4). We used $\mathrm{CRG}_{5-\mathrm{FU}}$ to evaluate the clinical relevance of candidate genes derived from 5-FU resistant cell line models (Figure 1). Due to the lack of other independent datasets for CRC patients with L-OHP-based chemotherapy, we treated the $\mathrm{CRG}_{5 \text {-FU/L-онР }}$ as the reference to evaluate the clinical relevance of BD genes and ID genes of L-OHP (Supplementary Methods).

\section{Clinical relevance of $\mathrm{BD}$ genes}

We defined $\mathrm{BD}_{\mathrm{two}}$ genes as those found in the overlap between the top-ranked $3000 \mathrm{BD}$ genes of 5-FU and L-OHP, which had the same deregulation directions in the drug-resistant cell lines compared with their corresponding parental cell lines(Supplementary Table 5). The consistency scores between $\mathrm{BD}_{\text {two }}$ genes and $\mathrm{CRG}_{5 \text {-FU/L-OHP }}$ were as low as $45 \%$ for the DEGs ranked by the FC method. The score was $64.44 \%$ for the DEGs ranked by the AD method (binomial test, $P$-value $=3.62 \mathrm{E}-02$, Table 3 ), suggesting significant but weak consistency between $\mathrm{BD}_{\text {two }}$ genes and $\mathrm{CRG}_{5-\mathrm{Fu} / \mathrm{L}-\mathrm{OHP}}$. In addition, We evaluated the clinical relevance of BD genes for each single drug. The corresponding consistency scores between the topranked $3000 \mathrm{BD}$ genes of 5-FU and $\mathrm{CRG}_{5 \text {-FU/L-OHP }}$ were $51.35 \%$ for the FC method and $68.57 \%$ for the AD method (Table 3). Similar results were observed when the $\mathrm{CRG}_{5 \text {-Fu }}$ were used as the reference to evaluate the clinical relevance of BD genes for 5-FU (Supplementary Table 6). For L-OHP, no significant consistency was observed between $\mathrm{BD}$ genes and $\mathrm{CRG}_{5 \text {-FU/L-OHP }}$ when ranking genes by either FC or AD (Table 3). For other CRC L-OHPresistant cell lines (DLD1, HT29, LS513 and Lovo) in the GSE10405 dataset, no significant consistency was observed between $\mathrm{BD}$ genes and $\mathrm{CRG}_{5 \text {-FU/L-OHP }}$ (Table 3).

Similar results were observed when analyzing the top-ranked $1500 \mathrm{BD}_{\text {two }}$ and $\mathrm{BD}$ genes ranked by $\mathrm{FC}$ or $\mathrm{AD}$ (Supplementary Table 7). These results suggest that the clinical relevance of $\mathrm{BD}$ genes is poor.

\section{Clinical relevance of ID genes}

We defined $\mathrm{ID}_{\text {two }}$ genes as the overlap of the top-ranked 3000 ID genes of 5-FU and L-OHP, which had the same deregulation directions in the drug-resistant cell lines treated with 5-FU or L-OHP compared with their corresponding 
Table 3: The consistency scores of $\mathrm{CRG}_{5-\mathrm{FU} / \mathrm{L}-\mathrm{OHP}}$ and the top-ranked $3000 \mathrm{BD}$ genes or ID genes

\begin{tabular}{|c|c|c|c|c|c|c|c|}
\hline Dataset & Drug & Cell line & Gene set & Method & $\begin{array}{c}\text { Overlapped } \\
\text { DEG }^{\mathrm{a}}\end{array}$ & Consistent DEG(\%) & $\begin{array}{c}\text { Binominal } \\
P \text {-value }\end{array}$ \\
\hline \multirow{8}{*}{ E-MEXP-390 } & \multirow{8}{*}{ 5-FU/ L-OHP } & \multirow{8}{*}{ HCT116 } & \multirow{2}{*}{$\mathrm{BD}_{\mathrm{two}}$} & $\mathrm{FC}$ & 40 & 45.00 & $>1.00 \mathrm{E}-01$ \\
\hline & & & & $\mathrm{AD}$ & 45 & 64.44 & $3.62 \mathrm{E}-02$ \\
\hline & & & \multirow{2}{*}{$\mathrm{ID}_{\text {two-6 }}$} & FC & 11 & 54.55 & $>1.00 \mathrm{E}-01$ \\
\hline & & & & $\mathrm{AD}$ & 24 & 54.17 & $>1.00 \mathrm{E}-01$ \\
\hline & & & \multirow{2}{*}{$\mathrm{ID}_{\mathrm{two}-12}$} & $\mathrm{FC}$ & 18 & 55.56 & $>1.00 \mathrm{E}-01$ \\
\hline & & & & $\mathrm{AD}$ & 33 & 57.58 & $>1.00 \mathrm{E}-01$ \\
\hline & & & \multirow{2}{*}{$\mathrm{ID}_{\mathrm{two}-24}$} & $\mathrm{FC}$ & 10 & 70.00 & $1.72 \mathrm{E}-01$ \\
\hline & & & & AD & 38 & 84.21 & $1.22 \mathrm{E}-05$ \\
\hline \multirow{8}{*}{ E-MEXP-390 } & \multirow{8}{*}{$5-\mathrm{FU}$} & \multirow{8}{*}{ HCT116 } & \multirow{2}{*}{$\mathrm{BD}$} & $\mathrm{FC}$ & 74 & 51.35 & $>1.00 \mathrm{E}-01$ \\
\hline & & & & AD & 70 & 68.57 & $1.27 E-03$ \\
\hline & & & \multirow{2}{*}{$\mathrm{ID}_{6}$} & $\mathrm{FC}$ & 79 & 55.70 & $>1.00 \mathrm{E}-01$ \\
\hline & & & & $\mathrm{AD}$ & 71 & 52.11 & $>1.00 \mathrm{E}-01$ \\
\hline & & & \multirow{2}{*}{$\mathrm{ID}_{12}$} & FC & 85 & 77.65 & 1.52E-07 \\
\hline & & & & AD & 89 & 74.16 & 2.85E-06 \\
\hline & & & \multirow{2}{*}{$\mathrm{ID}_{24}$} & $\mathrm{FC}$ & 79 & 55.70 & $>1.00 \mathrm{E}-01$ \\
\hline & & & & AD & 79 & 72.15 & 5.13E-05 \\
\hline \multirow{8}{*}{ E-MEXP-390 } & \multirow{8}{*}{ L-OHP } & \multirow{8}{*}{ HCT116 } & \multirow{2}{*}{$\mathrm{BD}$} & $\mathrm{FC}$ & 85 & 43.53 & $>1.00 \mathrm{E}-01$ \\
\hline & & & & $\mathrm{AD}$ & 78 & 57.69 & $>1.00 \mathrm{E}-01$ \\
\hline & & & \multirow{2}{*}{$\mathrm{ID}_{6}$} & $\mathrm{FC}$ & 60 & 50.00 & $>1.00 \mathrm{E}-01$ \\
\hline & & & & $\mathrm{AD}$ & 70 & 51.43 & $>1.00 \mathrm{E}-01$ \\
\hline & & & \multirow{2}{*}{$\mathrm{ID}_{12}$} & $\mathrm{FC}$ & 92 & 28.26 & $>1.00 \mathrm{E}-01$ \\
\hline & & & & $\mathrm{AD}$ & 82 & 35.37 & $>1.00 \mathrm{E}-01$ \\
\hline & & & \multirow{2}{*}{$\mathrm{ID}_{24}$} & FC & 71 & 74.65 & $1.94 \mathrm{E}-05$ \\
\hline & & & & AD & 71 & 83.10 & $6.74 \mathrm{E}-09$ \\
\hline \multirow{8}{*}{ GSE10405 } & \multirow{8}{*}{ L-OHP } & \multirow{2}{*}{ DLD1 } & \multirow{8}{*}{$\mathrm{BD}$} & FC & 20 & 70.00 & $>1.00 \mathrm{E}-01$ \\
\hline & & & & $\mathrm{AD}$ & 21 & 57.14 & $>1.00 \mathrm{E}-01$ \\
\hline & & \multirow{2}{*}{ HT29 } & & $\mathrm{FC}$ & 26 & 42.31 & $>1.00 \mathrm{E}-01$ \\
\hline & & & & $\mathrm{AD}$ & 16 & 43.75 & $>1.00 \mathrm{E}-01$ \\
\hline & & \multirow{2}{*}{ LS513 } & & $\mathrm{FC}$ & 18 & 55.56 & $>1.00 \mathrm{E}-01$ \\
\hline & & & & $\mathrm{AD}$ & 21 & 52.38 & $>1.00 \mathrm{E}-01$ \\
\hline & & \multirow{2}{*}{ Lovo } & & $\mathrm{FC}$ & 23 & 43.48 & $>1.00 \mathrm{E}-01$ \\
\hline & & & & $\mathrm{AD}$ & 15 & 53.33 & $>1.00 \mathrm{E}-01$ \\
\hline
\end{tabular}

Abbreviations: ID: inducible difference genes;

${ }^{a}$ The number of candidate drug resistance genes overlapped with $\mathrm{CRG}_{5-\mathrm{FU} / \mathrm{L}-\mathrm{OH}}$;

${ }^{\mathrm{b}}$ The consistency score of candidate drug resistance genes and $\mathrm{CRG}_{5-\mathrm{FU} / \mathrm{L}-\mathrm{OHP}}$ ' 


\section{A}

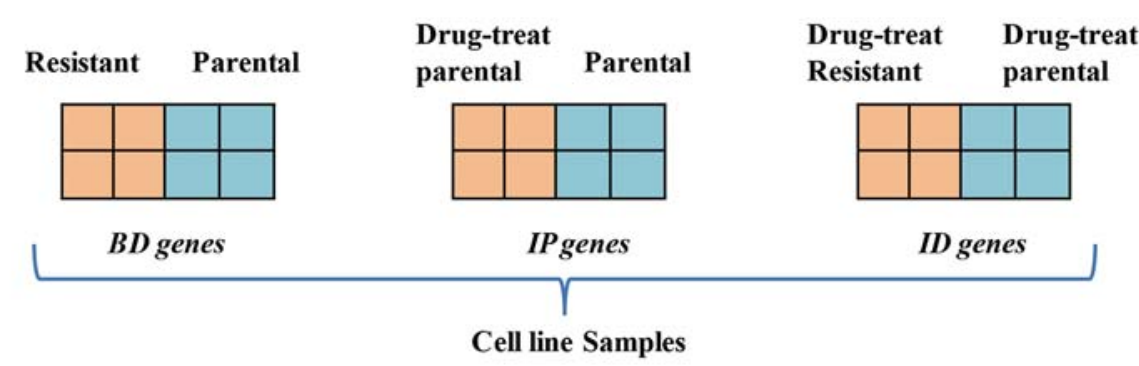

B

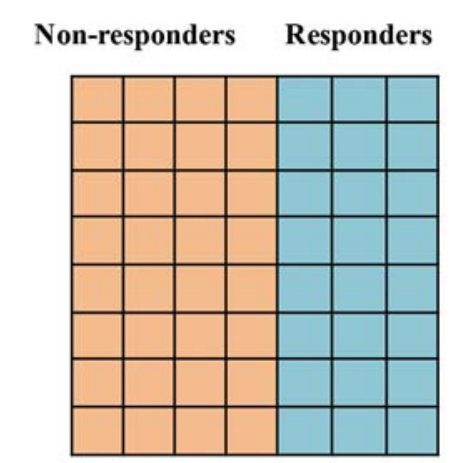

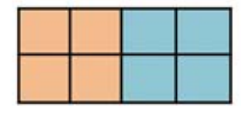

BD genes

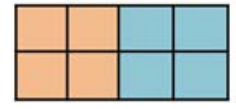

ID genes

Non-responders Responders

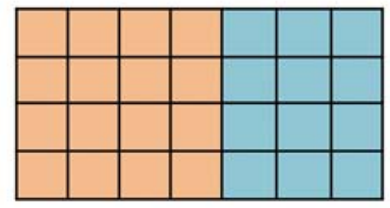

ID clinical $_{\text {genes }}$

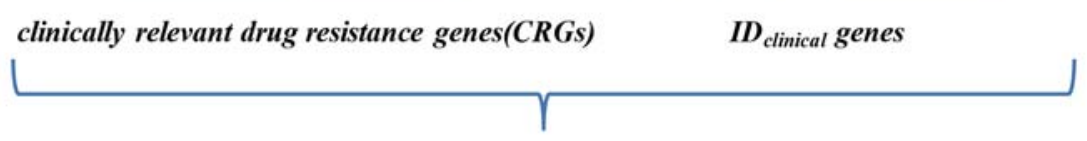

Evaluate the clinical relevance of candidate drug resistance genes

Figure 1: The main idea behind our approach. A. Three gene lists identified in drug-induced resistant cell models. B. Evaluation of clinical relevance of candidate drug resistance gene derived from drug-induced resistant cell models and post-chemotherapy cancer specimens. Abbreviations: BD genes: basally deregulated genes detected between parental cell line and resistant cell line; IP genes: genes detected between parental and drug-treated parental cells; ID genes: genes detected between drug-treat parental cell line and drug-treat resistant cell line; clinically relevant drug resistance genes (CRGs): DEGs between the pre-chemotherapy clinical specimens of responders and non-responders; $\mathrm{ID}_{\text {clinical }}$ genes: DEGs between the post-chemotherapy clinical specimens of responders and non-responders.

parental cell lines also treated with 5 -FU or L-OHP (Supplementary Table 5). The $\mathrm{ID}_{\mathrm{two}}$ genes were further denoted as $\mathrm{ID}_{\mathrm{two}}{ }^{-}, \mathrm{ID}_{\mathrm{two}}{ }^{-12}$ and $\mathrm{ID}_{\mathrm{two}}{ }^{-24}$ for the conditions where cells underwent drug treatment for 6, 12, and 24 hours, respectively. We then evaluated the clinical relevance of these genes. No significant consistency was observed for $\mathrm{ID}_{\text {two }}{ }^{-} 6$ and $\mathrm{ID}_{\mathrm{two}}{ }_{12}$ genes when ranking genes either by $\mathrm{FC}$ or $\mathrm{AD}$ (Table 3). For $\mathrm{ID}_{\mathrm{two}}{ }_{24}$ genes, however, the consistency score was as high as $84.21 \%$ when ranking genes by $\mathrm{AD}$ (binomial test, $P$-value $=1.22 \mathrm{E}-05)$. The score was also as high as $70 \%$ when ranking genes by $\mathrm{FC}$, although it did not reach significance. Similar results were observed when analyzing the top-ranked $1500 \mathrm{ID}_{\text {two }}$ genes (Supplementary Table7).

We further evaluated the clinical relevance of the top-ranked 3000 ID genes of 5-FU. When ranking genes by $\mathrm{FC}$, only $\mathrm{ID}_{12}$ genes were significantly consistent with $\mathrm{CRG}_{5 \text {-FUL-он, }}$, with a corresponding consistency score of $77.65 \%$ (binomial test, $P$-value $=1.52 \mathrm{E}-07$, Table 3 ). When ranking genes by $\mathrm{AD}$, however, significant consistency was observed for both $\mathrm{ID}_{12}$ and $\mathrm{ID}_{24}$ genes and the corresponding consistency scores were $74.16 \%$ (binomial test, $P$-value $=2.85 \mathrm{E}-06$ ) and $72.15 \%$ (binomial test, $P$-value $=5.13 \mathrm{E}-05$, Table 3), respectively. Similar results were observed when the $\mathrm{CRG}_{5-\mathrm{FU}}$ were used as the reference to evaluate the clinical relevance of ID genes for 5-FU (Supplementary Table 6). With regard to L-OHP, no significant consistency was observed for either $\mathrm{ID}_{6}$ or $\mathrm{ID}_{12}$ genes when ranking genes by either FC or AD (Table 3). For $\mathrm{ID}_{24}$ genes, however, the corresponding consistency scores were $74.65 \%$ when ranked by FC (binomial test, $P$-value $=1.94 \mathrm{E}-05$ ) and $83.10 \%$ by AD (binomial test, $P$-value $=6.74 \mathrm{E}-09$, Table 3 ). Similar results were observed when analyzing the top-ranked 1500 ID genes (Supplementary Table 7).

Additionally, we applied two-way analysis of variance to identify ID genes. The numbers of ID genes for L-OHP and 5-FU were 269 and 361 ( $P$-value $<5.00 \mathrm{E}-02)$, respectively, and they overlapped with only 6 and 3 of $\mathrm{CRG}_{5-\mathrm{FU} / \mathrm{L}-\mathrm{OHP}}$, respectively, due to the limited efficiency of variance estimation [22].

We found that the $\mathrm{ID}_{\text {two-24 }}$ genes, $\mathrm{BD}$ genes of $5-\mathrm{FU}$ and $\mathrm{ID}_{24}$ genes of $5-\mathrm{FU}$ detected by the 
$\mathrm{AD}$ method were more significantly consistent with $\mathrm{CRG}_{\text {5-FU/L-OHP }}$ compared with the FC method (Table 3). With regard to the $\mathrm{ID}_{\mathrm{two}-24}$ genes, there were 35 genes detected by AD but not FC. The average expression levels of these genes in parental cells treated with 5-FU for 24 hours and 5-FU-resistant cells treated with 5-FU for 24 hours were 1992.72 and 2322.72 (Figure 2A, Supplementary Table 8). The consistency score of these genes with $\mathrm{CRG}_{5 \text {-FU/L-OHP }}$ was $82.86 \%$ (binomial test, $P$-value $=5.84 \mathrm{E}-05$, Supplementary Table 8 ). By contrast, 7 genes detected by FC but not AD tended to have low expression levels and the corresponding average expression levels were 212.93 and 238.03 (Figure 2A, Supplementary Table 8). The corresponding consistency score was $57.14 \%$ (Supplementary Table 8). A similar result was also observed in L-OHP-resistant cells (Figure 2B, Supplementary Table 4). Subsequent analysis of $\mathrm{BD}$ genes of 5-FU and $\mathrm{ID}_{24}$ genes of 5-FU revealed similar results (Figure 2C-2D, Supplementary Table 8). These results demonstrate that $\mathrm{AD}$ is biased toward the identification of genes expressing at higher levels, whereas FC is biased at lower levels. Genes with low expression levels in both cell lines may reach large FCs simply due to measurement variations that create false positives [32].

It is worth noting that $\mathrm{ID}_{\text {two-24 }}$ and $\mathrm{ID}_{24}$ genes of both 5-FU and L-OHP had significant consistency with $\mathrm{CRG}_{5 \text {-FU/L-OHP }}$ while no significant consistency was observed in $\mathrm{ID}_{\text {two- } 6}$ and $\mathrm{ID}_{6}$ genes (Table 2). We combined $\mathrm{ID}_{24}$ genes detected by FC or AD method, which were significantly consistent with $\mathrm{CRG}_{5 \text {-FU/L-OHP, }}$ resulting in 70 genes of 5-FU resistance and 65 genes of L-OHP resistance (Supplementary Table 9). The $\log _{2}$ $F C$ values and $A D$ values of these genes are shown in Figure $3 \mathrm{~A}-3 \mathrm{D}$. We found that resistant genes of both 5-FU and L-OHP tended to change abruptly before the 24-hour time point. This result indicates that transient changes in expression levels might be unstable when the drug treatment time is short. It has been reported that many of the genes obtained above correlate with drug resistance, as exemplified in Supplementary Table 10 for the top $20 \mathrm{ID}_{24}$ genes ranked by $\mathrm{AD}$ method for each of the two drugs. TYMS is target of 5-FU and its overexpression can induce 5-FU resistance [33]. UNG can initiate base excision repair and its overexpression
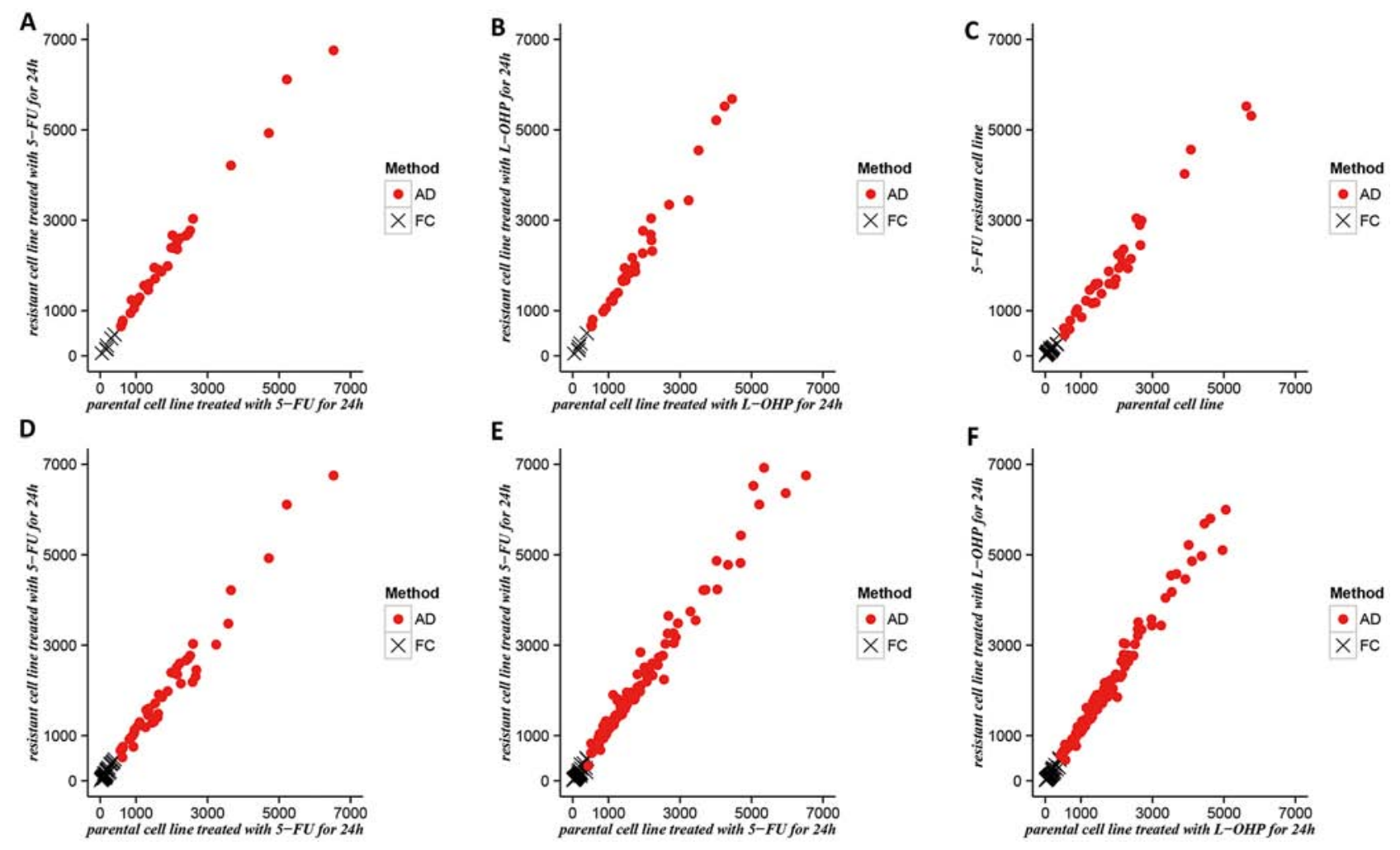

Figure 2: The distributions of DEGs exclusively detected by FC or AD. The average expression levels of DEGs exclusively detected by FC or AD were plotted. A-B. ID $_{\text {two-24 }}$ genes compared with $\mathrm{CRG}_{5-\mathrm{FU} / \mathrm{L}-\mathrm{OHP}}$ in parental cell line treated with 5-FU(or L-OHP) for $24 \mathrm{~h}$ and resistant cell line treated with 5-FU(or L-OHP) for $24 \mathrm{~h}$; C. BD genes of 5-FU compared with CRG 5 -FU/L-OHP in parental cell line and 5-FU resistant cell line; D. $\mathrm{ID}_{24}$ genes of 5-FU compared with $\mathrm{CRG}_{5-\mathrm{FU} / \mathrm{L}-\mathrm{OHP}}$ in parental cell line treated with 5-FU for $24 \mathrm{~h}$ and resistant

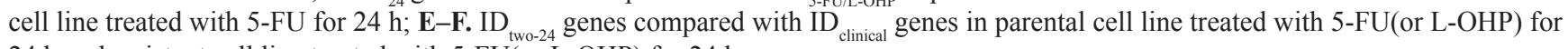
$24 \mathrm{~h}$ and resistant cell line treated with 5-FU( or L-OHP) for $24 \mathrm{~h}$; 

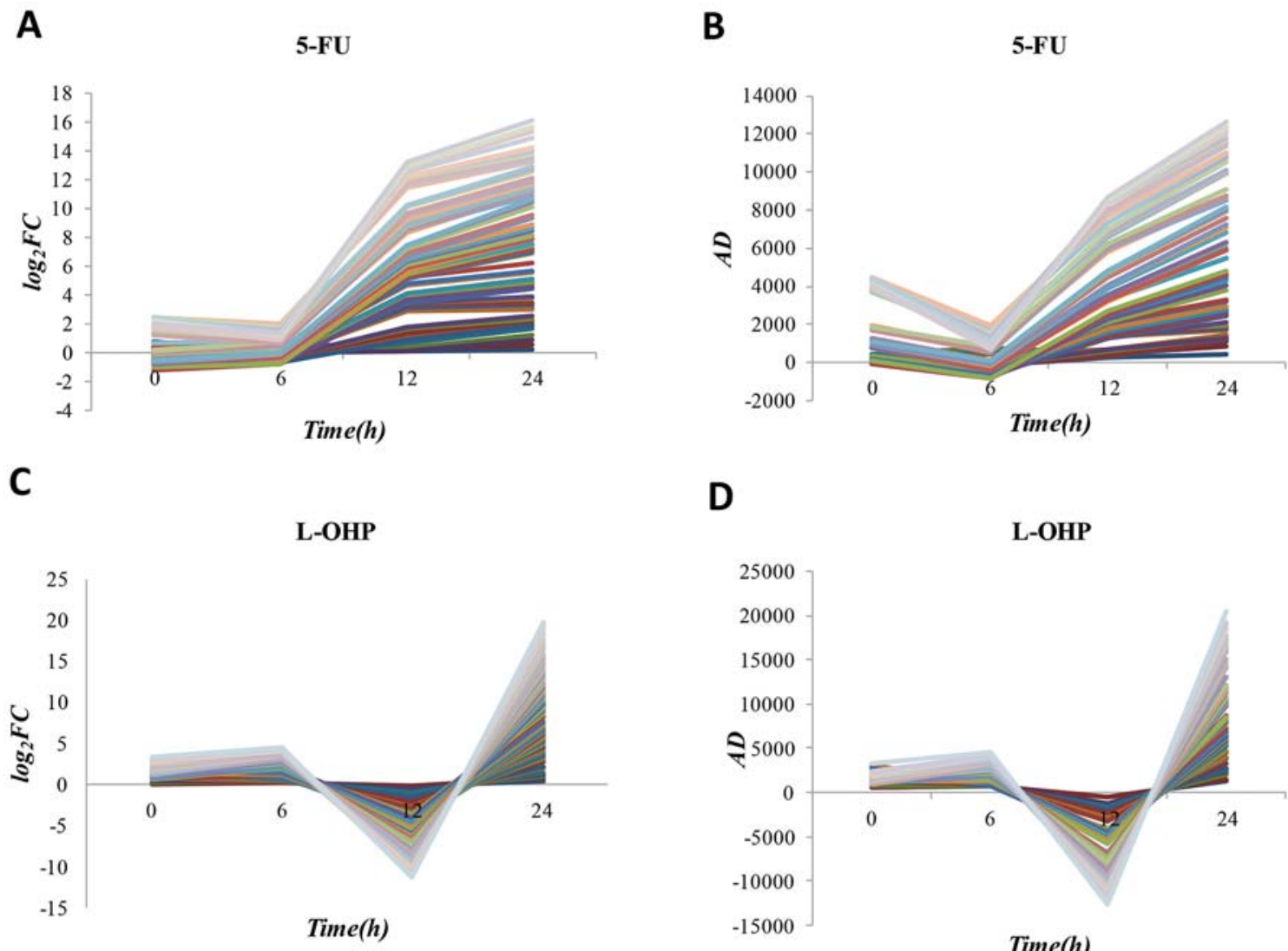

D

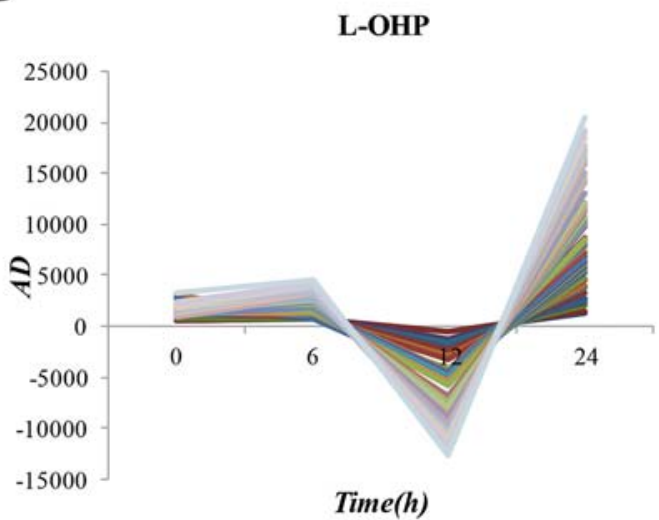

Figure 3: The $\log 2 \mathrm{FC}$ values and $A D$ values of 70 genes of 5-FU resistance and 65 genes of L-OHP resistance. A-B. The $\log _{2} \mathrm{FC}$ values and AD values of 70 genes of 5-FU resistance in parental cell line treated with 5-FU for $24 \mathrm{~h}$ and resistant cell line treated with 5-FU for $24 \mathrm{~h}$; C-D. The $\log _{2} \mathrm{FC}$ values and AD values of 65 genes of L-OHP resistance in parental cell line treated with L-OHP for $24 \mathrm{~h}$ and resistant cell line treated with L-OHP for $24 \mathrm{~h}$.

may stimulate the development of L-OHP resistance [34]. Up-regulation of PSAT1 stimulates cell growth and increases chemoresistance of colon cancer cells to L-OHP [35]. TTK, MCM2, CLDN7 and TSPAN13 promote tumor cell proliferation and their overexpression could stimulate drug resistance [36-39].

\section{Pathway analysis of $\mathrm{ID}_{24}$ genes}

Functional enrichment analysis showed that the top $3000 \mathrm{ID}_{24}$ genes of 5-FU separately ranked by FC and $\mathrm{AD}$ were enriched in 6 and 22 pathways, respectively (FDR $<0.1$, Supplementary Table 11). With regard to L-OHP, the top $3000 \mathrm{ID}_{24}$ genes separately ranked by FC and $\mathrm{AD}$ were enriched in 14 and 31 pathways, respectively (FDR $<0.1$, Supplementary Table 11 ). It has been reported that many of the pathways enriched with $\mathrm{ID}_{24}$ genes could mediate drug resistance of the corresponding drug, as described in the Supplementary Table 11. Genes detected by the AD method but not FC were significantly enriched mostly in more conserved pathways with important biological significance, including glycolysis/ gluconeogenesis, citrate cycle (TCA cycle), fatty acid degradation and glutathione metabolism. It has been found that targeting metabolic enzymes in the glycolytic pathway, citric acid cycle and fatty acid synthesis could enhance the efficacy of common therapeutic agents and overcome resistance to chemotherapy [40]. Elevation of glutathione metabolism pathway involved in the deactivation of anticancer agents [41]. Several inhibitors which have been reported to target the corresponding pathways were listed in the Supplementary Table 12.

\section{Identification of ID genes based on post-chemotherapy CRC specimens}

We denoted $\mathrm{ID}_{\text {clinical }}$ genes as DEGs between the postchemotherapy CRC specimens of responders and nonresponders, which are similar to ID genes that represent the difference between two cell types in response to drug treatment. Using the RankProduct method, we detected $1725 \mathrm{ID}_{\text {clinical }}$ genes $(\mathrm{FDR}<0.1)$, with the consistency score between $\mathrm{ID}_{\text {clinical }}$ genes and $\mathrm{CRG}_{5 \text {-FU/L-OHP }}\left(\mathrm{CRG}_{5 \text {-FU }}\right)$ as high as $83.85 \%(88.46 \%)$ (binomial test, $P$-value $<1.11 \mathrm{E}-16$, Supplementary Table 13). Furthermore, the consistency score between $\mathrm{ID}_{\text {clinical }}$ genes and the top-ranked 3000 
ID $_{\text {two-24 }}$ detected by the AD method was $73.57 \%$ (binomial test, $P$-value $<1.09 \mathrm{E}-08$, Supplementary Table 13 ). Both $\mathrm{ID}_{\text {two-24 }}$ and $\mathrm{ID}_{24}$ genes were substantially more consistent with $\mathrm{ID}_{\text {clinical }}$ genes than $\mathrm{ID}_{\text {two-6 }}, \mathrm{ID}_{\text {two-12, }} \mathrm{ID}_{6}$, and $\mathrm{ID}_{12}$ (Supplementary Table 13) Similar results were observed when analyzing the top-ranked 1500 ID genes ranked by FC or AD (Supplementary Table 13). In addition, the $\mathrm{ID}_{\text {two-24 }}$ genes detected by the AD method were also more significantly consistent with $\mathrm{ID}_{\text {clinical }}$ genes compared with the FC method (Supplementary Table 8, Figure 2E-2F).

\section{DISCUSSION}

Current cancer therapeutics are generally dosed in combination [42, 43]. This makes it difficult to directly study drug resistance mechanisms for any single drug in clinical cohorts. Thus, using cell models would be the only practical choice for identifying resistant signatures for individual drugs [7, 44-46] although the clinical relevance of cancer cell models has been continuously questioned [10-14]. Our results demonstrated that, rather than BD genes, ID genes which represented the difference between parental and resistant cells in response to drug treatment would be more likely to be involved in drug resistance. Moreover, our analysis supports that samples taken after neoadjuvant chemotherapy can be used to ascertain functional drug resistance signatures $[47,48]$.

One caveat of our analysis for identifying ID genes is that expression profiles of drug-treated cells were only measured at 6,12 , and 24 hours, which might be insufficient to investigate the characteristics of sustained responses $[49,50]$. It would be possible that the difference between two types of cell in sustained response to drug treatment might be more likely relevant with drug resistance. Hence, it is necessary to design experiments with prolonged time of drug treatment and to further characterize the dynamic transcriptome change. Another problem is that many factors such as the choice of a parent cell line, drug dose and treatment interval are associated with the drug resistance level of the drug-induced resistant cell [51]. A reasonable assumption would be that using cell models with higher level of drug resistance might have larger chance to find drug resistance genes, which deserves our future study. The third problem is that the CRGs identified from pre-chemotherapy specimens represent inherent resistance genes, whereas the process of inducing a drug sensitive cell to become a drug resistant cell by drug treatment might mimic the process of acquiring drug resistance for clinical patients during chemotherapy. However, it has been suggested that there might be no obvious boundaries between inherent drug resistance genes and acquired drug resistance genes [52, 53]. In fact, the significant consistency between the ID genes and the corresponding CRGs could be regarded as evidence supporting the notion that the two type genes might be largely consistent $[52,53]$.

In summary, this pilot study on CRC suggests a novel experimental analysis strategy to extract clinically relevant drug-resistance signatures from drug-induced resistant cell models. It also suggests that tumor tissue samples taken at definitive surgery after chemotherapy could be useful for identifying drug-resistance signatures.

\section{MATERIALS AND METHODS}

\section{Data acquisition and processing}

The transcriptional profiles of 30 postchemotherapy CRC specimens were submitted to Gene Expression Omnibus (GEO) under accession number GSE69657. All patients underwent neoadjuvant FOLFOX4 chemotherapy, and there were 13 responders and 17 non-responders according to the Response Evaluation Criteria in Solid Tumors (RECIST) [54]. The detailed experimental protocols were described in a previous study [55]. All other datasets analyzed in this study were downloaded from GEO and ArrayExpress (Table 1). The datasets generated from the Affymetrix microarray platform were pre-processed using the robust microarray average (RMA) algorithm and the other datasets generated from the Illumina and Agilent microarray platform were log2-transformed and quantile normalized. Normalization of GSE10405 was performed with Lowess and Dye Swap Sim Fix Filter methods [56]. Each probe-set ID was mapped to its Entrez gene ID. If multiple probe-sets were mapped to the same gene, the expression value for the gene was defined as the arithmetic mean of the values of the multiple probe-sets.

\section{Reproducibility evaluation of DEGs from independent datasets}

For DEGs from two independent datasets, sharing $\mathrm{k}$ DEGs, of which s genes had the same deregulation directions (both up-regulated or down-regulated in the two gene lists), the consistency score was calculated as $\mathrm{s} / \mathrm{k}$. The probability of observing at least s of $\mathrm{k}$ DEGs with the same deregulation directions by chance can be evaluated using the cumulative binomial distribution model as follows:

$$
p=1-\sum_{i=0}^{s-1}\left(\begin{array}{l}
k \\
i
\end{array}\right)\left(p_{e}\right)^{i}\left(1-p_{e}\right)^{k-i}
$$

where $p_{e}$ is the probability of one gene having the same deregulation directions in two gene lists by random chance (here, $p_{e}=0.5$ ). 


\section{Selection of clinically relevant drug resistance genes}

We have made a strict mathematical derivation to prove that if two different regimens share one or several drugs, then the overlaps of CRGs for the two different regimens should be the CRGs for the shared drug(s) under the assumption that the drugs used in combination had no (or limited) antagonistic effects(Supplementary Methods). The RankProduct method [31], which is resistant to batch effects, was applied to identify DEGs between responders and non-responders. Using 52 samples collected from three independent datasets (Table 1), we selected and evaluated the reproducibility of the $\mathrm{CRG}_{5 \text {-FU/L-OHP }}$ The GSE52735 dataset including 37 samples was used to select the $\mathrm{CRG}_{5-\mathrm{FU}}$. The $p$-values were adjusted using the Benjamini and Hochberg procedure [57].

\section{Selection of DEGs from cell lines}

The non-log-transformed average expression values of gene $i$ in the drug-resistant sample and parental sample were denoted as $X_{i}^{A}$ and $X_{i}^{B}$, respectively. Then, the FC for each gene $i$ between the two samples was calculated as follows:

$$
F C_{i}=\frac{X_{i}^{A}}{X_{i}^{B}}
$$

The AD for each gene $i$ between the two samples was calculated as follows:

$$
A D_{i}=X_{i}^{A}-X_{i}^{B}
$$

All genes were sorted in descending order according to $\mathrm{FC}$ or $\mathrm{AD}$. If the value of $F C_{i}$ was larger (or smaller) than one, then gene $i$ was defined as up-regulated (or down-regulated) in resistant samples. Similarly, if the value of $A D_{i}$ was larger (or smaller) than zero, gene $i$ was defined as up-regulated (or down-regulated) in resistant samples.

\section{Pathway enrichment analysis}

Functional enrichment analysis was performed based on the Kyoto Encyclopedia of Genes and Genomes [58]. The hypergeometric distribution model was used to identify biological pathways that were significantly enriched with DEGs.

\section{CONFLICTS OF INTEREST}

No potential conflicts of interest were disclosed.

\section{GRANT SUPPORT}

This work was supported by the National Natural Science Foundation of China(Grant Nos. 81572935 and 81372213, 81501215, 81501829).

\section{REFERENCES}

1. Hansen SN, Westergaard D, Thomsen MB, Vistesen M, Do KN, Fogh L, Belling $\mathrm{KC}$, Wang J, Yang $\mathrm{H}$, Gupta R, Ditzel HJ, Moreira J, Brunner N, Stenvang J, Schrohl AS. Acquisition of docetaxel resistance in breast cancer cells reveals upregulation of ABCB1 expression as a key mediator of resistance accompanied by discrete upregulation of other specific genes and pathways. Tumour Biol. 2015; 36:4327-38.

2. Shen Y, Pan Y, Xu L, Chen L, Liu L, Chen H, Chen Z, Meng Z. Identifying microRNA-mRNA regulatory network in gemcitabine-resistant cells derived from human pancreatic cancer cells. Tumour Biol. 2015; 36:4525-34.

3. von der Heyde S, Wagner S, Czerny A, Nietert M, Ludewig F, Salinas-Riester G, Arlt D, Beissbarth T. mRNA profiling reveals determinants of trastuzumab efficiency in HER2-positive breast cancer. PLoS One. 2015; 10:e117818.

4. Chen Z, Zhang L, Xia L, Jin Y, Wu Q, Guo H, Shang X, Dou J, Wu K, Nie Y, Fan D. Genomic analysis of drug resistant gastric cancer cell lines by combining mRNA and microRNA expression profiling. Cancer Lett. 2014; 350:43-51.

5. Nakamura A, Nakajima G, Okuyama R, Kuramochi H, Kondoh Y, Kanemura T, Takechi T, Yamamoto M, Hayashi K. Enhancement of 5-fluorouracil-induced cytotoxicity by leucovorin in 5-fluorouracil-resistant gastric cancer cells with upregulated expression of thymidylate synthase. Gastric Cancer. 2014; 17:188-195.

6. Zhang YW, Zheng Y, Wang JZ, Lu XX, Wang Z, Chen LB, Guan XX, Tong JD. Integrated analysis of DNA methylation and mRNA expression profiling reveals candidate genes associated with cisplatin resistance in non-small cell lung cancer. Epigenetics. 2014; 9:896-909.

7. Zheng Y, Zhou J, Tong Y. Gene signatures of drug resistance predict patient survival in colorectal cancer. Pharmacogenomics J. 2015; 15:135-143.

8. Moutinho C, Martinez-Cardus A, Santos C, Navarro-Perez V, Martinez-Balibrea E, Musulen E, Carmona FJ, SartoreBianchi A, Cassingena A, Siena S, Elez E, Tabernero J, Salazar R, Abad A, Esteller M. Epigenetic inactivation of the BRCA1 interactor SRBC and resistance to oxaliplatin in colorectal cancer. J Natl Cancer Inst. 2014; 106:djt322.

9. Stevenson L, Allen WL, Turkington R, Jithesh PV, Proutski I, Stewart G, Lenz HJ, Van Schaeybroeck S, Longley DB, Johnston PG. Identification of galanin and its receptor GalR1 as novel determinants of resistance to chemotherapy and potential biomarkers in colorectal cancer. Clin Cancer Res. 2012; 18:5412-5426.

10. Anderson AC. Possible paths and potential barriers to successfully modeling drug resistance. Future Med Chem. 2013; 5:1181-1183.

11. Gillet JP, Varma S, Gottesman MM. The clinical relevance of cancer cell lines. J Natl Cancer Inst. 2013; 105:452-458. 
12. Gillet JP, Calcagno AM, Varma S, Marino M, Green LJ, Vora MI, Patel C, Orina JN, Eliseeva TA, Singal V, Padmanabhan R, Davidson B, Ganapathi R, Sood AK, Rueda BR, Ambudkar SV, et al. Redefining the relevance of established cancer cell lines to the study of mechanisms of clinical anti-cancer drug resistance. Proc Natl Acad Sci U S A. 2011; 108:18708-18713.

13. Borst P, Wessels L. Do predictive signatures really predict response to cancer chemotherapy? Cell Cycle. 2010; 9:4836-4840.

14. Borrell B. How accurate are cancer cell lines?. Nature. 2010; 463:858.

15. Boyer J, Allen WL, McLean EG, Wilson PM, McCulla A, Moore S, Longley DB, Caldas C, Johnston PG. Pharmacogenomic identification of novel determinants of response to chemotherapy in colon cancer. Cancer Res. 2006; 66:2765-2777.

16. Allen WL, Turkington RC, Stevenson L, Carson G, Coyle VM, Hector S, Dunne P, Van Schaeybroeck S, Longley DB, Johnston PG. Pharmacogenomic profiling and pathway analyses identify MAPK-dependent migration as an acute response to SN38 in p53 null and p53-mutant colorectal cancer cells. Mol Cancer Ther. 2012; 11:1724-1734.

17. Allen WL, Coyle VM, Jithesh PV, Proutski I, Stevenson L, Fenning C, Longley DB, Wilson RH, Gordon M, Lenz HJ, Johnston PG. Clinical determinants of response to irinotecan-based therapy derived from cell line models. Clin Cancer Res. 2008; 14:6647-6655.

18. Munkacsy G, Abdul-Ghani R, Mihaly Z, Tegze B, Tchernitsa O, Surowiak P, Schafer R, Gyorffy B. PSMB7 is associated with anthracycline resistance and is a prognostic biomarker in breast cancer. Br J Cancer. 2010; 102:361-368.

19. Li J, Wood WH 3rd, Becker KG, Weeraratna AT, Morin PJ. Gene expression response to cisplatin treatment in drugsensitive and drug-resistant ovarian cancer cells. Oncogene. 2007; 26:2860-2872.

20. Tusher VG, Tibshirani R, Chu G. Significance analysis of microarrays applied to the ionizing radiation response. Proc Natl Acad Sci U S A. 2001; 98:5116-5121.

21. Feten G, Aastveit AH, Snipen L, Almoy T. A discussion concerning the inclusion of variety effect when analysis of variance is used to detect differentially expressed genes. Gene Regul Syst Bio. 2007; 1:43-47.

22. Jeffery IB, Higgins DG, Culhane AC. Comparison and evaluation of methods for generating differentially expressed gene lists from microarray data. BMC Bioinformatics. 2006; $7: 359$.

23. Kadota K, Nakai Y, Shimizu K. A weighted average difference method for detecting differentially expressed genes from microarray data. Algorithms Mol Biol. 2008; 3:8.

24. Chen JJ, Tsai CA, Tzeng S, Chen CH. Gene selection with multiple ordering criteria. BMC Bioinformatics. 2007; 8:74.
25. Obenauf AC, Zou Y, Ji AL, Vanharanta S, Shu W, Shi H, Kong X, Bosenberg MC, Wiesner T, Rosen N, Lo RS, Massague J. Therapy-induced tumour secretomes promote resistance and tumour progression. Nature. 2015; 520:368-372.

26. Asangani IA, Dommeti VL, Wang X, Malik R, Cieslik M, Yang R, Escara-Wilke J, Wilder-Romans K, Dhanireddy S, Engelke C, Iyer MK, Jing X, Wu YM, Cao X, Qin ZS, Wang $\mathrm{S}$, et al. Therapeutic targeting of BET bromodomain proteins in castration-resistant prostate cancer. Nature. $2014 ; 510: 278-282$.

27. Lin X, Li J, Yin G, Zhao Q, Elias D, Lykkesfeldt AE, Stenvang J, Brunner N, Wang J, Yang H, Bolund L, Ditzel HJ. Integrative analyses of gene expression and DNA methylation profiles in breast cancer cell line models of tamoxifen-resistance indicate a potential role of cells with stem-like properties. Breast Cancer Res. 2013; 15:R119.

28. Leek JT, Scharpf RB, Bravo HC, Simcha D, Langmead B, Johnson WE, Geman D, Baggerly K, Irizarry RA. Tackling the widespread and critical impact of batch effects in highthroughput data. Nat Rev Genet. 2010; 11:733-739.

29. Ao L, Yan H, Zheng T, Wang H, Tong M, Guan Q, Li X, Cai H, Li M, Guo Z. Identification of reproducible drugresistance-related dysregulated genes in small-scale cancer cell line experiments. Sci Rep. 2015; 5:11895.

30. Schaefer MH, Yang JS, Serrano L, Kiel C. Protein conservation and variation suggest mechanisms of cell typespecific modulation of signaling pathways. PLoS Comput Biol. 2014; 10:e1003659.

31. Breitling R, Armengaud P, Amtmann A, Herzyk P. Rank products: a simple, yet powerful, new method to detect differentially regulated genes in replicated microarray experiments. FEBS Lett. 2004; 573:83-92.

32. Zhang M, Yao C, Guo Z, Zou J, Zhang L, Xiao H, Wang D, Yang D, Gong X, Zhu J, Li Y, Li X. Apparently low reproducibility of true differential expression discoveries in microarray studies. Bioinformatics. 2008; 24:2057-2063.

33. Temraz S, Mukherji D, Alameddine R, Shamseddine A. Methods of overcoming treatment resistance in colorectal cancer. Crit Rev Oncol Hematol. 2014; 89:217-230.

34. Seetharam R, Sood A, Goel S. Oxaliplatin: pre-clinical perspectives on the mechanisms of action, response and resistance. Ecancermedicalscience. 2009; 3:153.

35. Vie N, Copois V, Bascoul-Mollevi C, Denis V, Bec N, Robert B, Fraslon C, Conseiller E, Molina F, Larroque C, Martineau P, Del Rio M, Gongora C. Overexpression of phosphoserine aminotransferase PSAT1 stimulates cell growth and increases chemoresistance of colon cancer cells. Mol Cancer. 2008; 7:14.

36. Kaistha BP, Honstein T, Muller V, Bielak S, Sauer M, Kreider R, Fassan M, Scarpa A, Schmees C, Volkmer H, Gress TM, Buchholz M. Key role of dual specificity kinase TTK in proliferation and survival of pancreatic cancer cells. Br J Cancer. 2014; 111:1780-1787. 
37. Niittymaki I, Gylfe A, Laine L, Laakso M, Lehtonen HJ, Kondelin J, Tolvanen J, Nousiainen K, Pouwels J, Jarvinen H, Nuorva K, Mecklin JP, Makinen M, Ristimaki A, Orntoft TF, Hautaniemi S, et al. High frequency of TTK mutations in microsatellite-unstable colorectal cancer and evaluation of their effect on spindle assembly checkpoint. Carcinogenesis. $2011 ; 32: 305-311$.

38. Kim CJ, Lee JW, Choi JJ, Choi HY, Park YA, Jeon HK, Sung CO, Song SY, Lee YY, Choi CH, Kim TJ, Lee JH, Kim BG, Bae DS. High claudin-7 expression is associated with a poor response to platinum-based chemotherapy in epithelial ovarian carcinoma. Eur J Cancer. 2011; 47:918-925.

39. Darido C, Buchert M, Pannequin J, Bastide P, Zalzali H, Mantamadiotis T, Bourgaux JF, Garambois V, Jay P, Blache $\mathrm{P}$, Joubert D, Holle F. Defective claudin-7 regulation by Tcf- 4 and Sox- 9 disrupts the polarity and increases the tumorigenicity of colorectal cancer cells. Cancer Res. 2008; 68:4258-4268.

40. Zhao Y, Butler EB, Tan M. Targeting cellular metabolism to improve cancer therapeutics. Cell Death Dis. 2013; 4:e532.

41. Kibria G, Hatakeyama H, Harashima H. Cancer multidrug resistance: mechanisms involved and strategies for circumvention using a drug delivery system. Arch Pharm Res. 2014; 37:4-15.

42. Al-Lazikani B, Banerji U, Workman P. Combinatorial drug therapy for cancer in the post-genomic era. Nat Biotechnol. 2012; 30:679-692.

43. Chabner BA Roberts TG Jr. Timeline: Chemotherapy and the war on cancer. Nat Rev Cancer. 2005; 5:65-72.

44. Ferriss JS, Kim Y, Duska L, Birrer M, Levine DA, Moskaluk C, Theodorescu D, Lee JK. Multi-gene expression predictors of single drug responses to adjuvant chemotherapy in ovarian carcinoma: predicting platinum resistance. PLoS One. 2012; 7:e30550.

45. Liedtke C, Wang J, Tordai A, Symmans WF, Hortobagyi GN, Kiesel L, Hess K, Baggerly KA, Coombes KR, Pusztai L. Clinical evaluation of chemotherapy response predictors developed from breast cancer cell lines. Breast Cancer Res Treat. 2010; 121:301-309.

46. Lee JK, Havaleshko DM, Cho H, Weinstein JN, Kaldjian EP, Karpovich J, Grimshaw A, Theodorescu D. A strategy for predicting the chemosensitivity of human cancers and its application to drug discovery. Proc Natl Acad Sci U S A. 2007; 104:13086-13091.

47. Basik M, Aguilar-Mahecha A, Rousseau C, Diaz Z, Tejpar S, Spatz A, Greenwood CM, Batist G. Biopsies: next-generation biospecimens for tailoring therapy. Nat Rev Clin Oncol. 2013; 10:437-450.
48. Loi S, Symmans WF, Bartlett JM, Fumagalli D, Van’t Veer L, Forbes JF, Bedard P, Denkert C, Zujewski J, Viale G, Pusztai L, Esserman LJ, Leyl-Jones BR. Proposals for uniform collection of biospecimens from neoadjuvant breast cancer clinical trials: timing and specimen types. Lancet Oncol. 2011; 12:1162-1168.

49. Qu XA, Rajpal DK. Applications of Connectivity Map in drug discovery and development. Drug Discov Today. 2012; 17:1289-1298.

50. Bar-Joseph Z, Gitter A, Simon I. Studying and modelling dynamic biological processes using time-series gene expression data. Nat Rev Genet. 2012; 13:552-564.

51. McDermott M, Eustace AJ, Busschots S, Breen L, Crown J, Clynes M, O’Donovan N, Stordal B. In vitro Development of Chemotherapy and Targeted Therapy Drug-Resistant Cancer Cell Lines: A Practical Guide with Case Studies. Front Oncol. 2014; 4:40.

52. Turner NC, Reis-Filho JS. Genetic heterogeneity and cancer drug resistance. Lancet Oncol. 2012; 13:e178-185.

53. Chapal N, Molina L, Molina F, Laplanche M, Pau B, Petit P. Pharmacoproteomic approach to the study of drug mode of action, toxicity, and resistance: applications in diabetes and cancer. Fundam Clin Pharmacol. 2004; 18:413-422.

54. Therasse P, Arbuck SG, Eisenhauer EA, Wanders J, Kaplan RS, Rubinstein L, Verweij J, Van Glabbeke M, van Oosterom AT, Christian MC, Gwyther SG. New guidelines to evaluate the response to treatment in solid tumors. European Organization for Research and Treatment of Cancer, National Cancer Institute of the United States, National Cancer Institute of Canada. J Natl Cancer Inst. 2000; 92:205-216.

55. Li S, Lu X, Chi P, Pan J. Identification of HOXB8 and KLK11 expression levels as potential biomarkers to predict the effects of FOLFOX4 chemotherapy. Future Oncol. 2013; 9:727-736.

56. Martinez-Cardus A, Martinez-Balibrea E, Bandres E, Malumbres R, Gines A, Manzano JL, Taron M, GarciaFoncillas J, Abad A. Pharmacogenomic approach for the identification of novel determinants of acquired resistance to oxaliplatin in colorectal cancer. Mol Cancer Ther. 2009; 8:194-202.

57. Benjamini Y, Drai D, Elmer G, Kafkafi N, Golani I. Controlling the false discovery rate in behavior genetics research. Behav Brain Res. 2001; 125:279-284.

58. Kanehisa M, Goto S, Sato Y, Furumichi M, Tanabe M. KEGG for integration and interpretation of largescale molecular data sets. Nucleic Acids Res. 2012; 40:D109-114. 